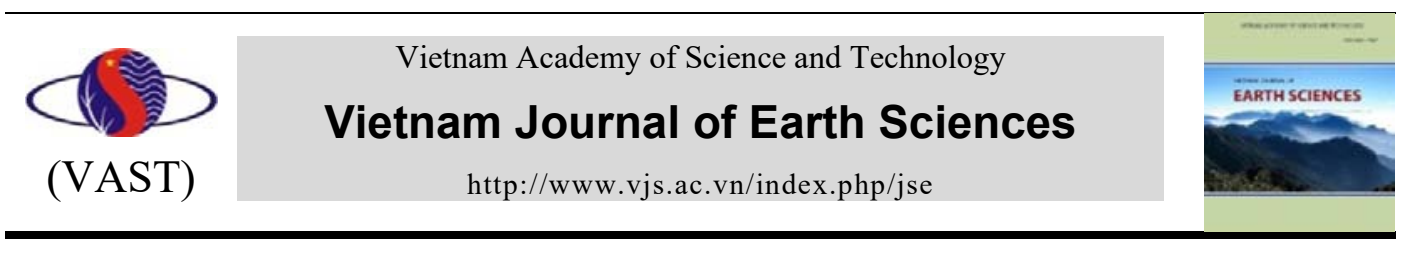

\title{
Spatial variations of arsenic in groundwater from a transect in the Northwestern Hanoi
}

\author{
Dao Viet Nga1, Pham Thi Kim Trang1, Vu Thi Duyen¹, Tran Thi Mai1, Vi Thi Mai Lan¹, \\ Pham Hung Viet*1, Dieke Postma², Rasmus J akobsen² \\ ${ }^{1}$ Research center for Environmental Technology and Sustainable Development (CETASD), \\ VNU University of Science \\ ${ }^{2}$ Geological Survey of Denmark and Greenland (GEUS), Denmark
}

Received 5 April 2017; Received in revised form 3 July 2017; Accepted 8 December 2017

\begin{abstract}
Arsenic contamination of groundwater is a major health problem and has been a growing concern in the last decade in several regions of the world, especially in South and Southeast Asia, including the Red River Delta, Vietnam. Regional groundwater studies have been carried out in the vicinity of Hanoi, on the banks of the Red River and its adjacent floodplains. In this study, the groundwater from a transect in the Northwestern area of Hanoi was examined. The results showed that $28.8 \%$ the wells of the B-B' transect exceed the WHO guideline value for arsenic concentration in drinking water. The arsenic concentrations varied in a wide range from point to point, with the highest concentration found at Van Phuc and the lowest one found at Cam Yen. They also varied accordingly to the depth.
\end{abstract}

Keywords: Arsenic; groundwater; Northwestern Hanoi.

(C)2018 Vietnam Academy of Science and Technology

\section{Introduction}

Arsenic is a naturally occurring element in the Earth's crust. In its natural form in soil, arsenic is harmless. However, if arsenic contaminates the water and food chain, it will be a threat to human health and other living organisms as it can cause skin, kidney, lung, liver and bladder cancer (Anawar et al., 2004). Drinking water constitutes a major pathway of exposure to arsenic in humans. Drinking water is derived from a variety of sources such as surface water, groundwater and rainwater

"Corresponding author, Email: phamhungviet@hus.edu.vn
(Smedley, Kinniburgh, 2002). Among those sources, groundwater is generally more vulnerable to arsenic contamination than surface water due to the potential interaction between groundwater and the minerals in soil which is favorable for arsenic release (Smedley, 2006). WHO has given the guideline value for arsenic in groundwater and drinking water is 50 and $10 \mu \mathrm{g} / \mathrm{L}$, respectively (WHO, 2011).

There have been incidents of groundwater with arsenic contamination reported in several regions of the world. Some of the most serve cases of groundwater contaminated with arsenic occurred in aquifers from South and Southeast Asia (e.g. Bengal delta, Vietnam, 
Cambodia, etc). Study on the arsenic concentrations in 6000 tube wells in a $25 \mathrm{~km}^{2}$ area of Bangladesh of van Geen et al. (2003) showed the range of arsenic concentrations from $<5$ to $900 \mu \mathrm{g} / \mathrm{L}$, with more than half of the wells did not meet the Bangladesh standard for drinking water $(50 \mu \mathrm{g} / \mathrm{L})$. In West Bengal (India), Chowdhury et al. (2000) studied nine affected districts and found that $55 \%$ and $34 \%$ of the tube wells contained arsenic above 10 and 50 $\mu \mathrm{g} / \mathrm{L}$, respectively.

In Southeast Asia, many researches were also carried out. In Cambodia, the arsenic concentrations ranged from 1-1610 $\mu \mathrm{g} / \mathrm{L}$ (average $217 \mu \mathrm{g} / \mathrm{L}$ ) and these figures were 1-845 $\mu \mathrm{g} / \mathrm{L}$ (average $39 \mu \mathrm{g} / \mathrm{L}$ ) in Southern Vietnam (Berg et al., 2006). A similar predicament has been discovered in the Red River Basin, Vietnam. Berg et al. (2001) studied the groundwater of four rural districts around Hanoi (which are Dong Anh, Tu Liem, Gia Lam and Thanh Tri) and reported that the average arsenic concentrations varied from 1 to $3050 \mu \mathrm{g} / \mathrm{L}$, with the mean value being $159 \mu \mathrm{g} / \mathrm{L}$. This is the first report on high arsenic concentrations in groundwater of the Red River Basin. Since then, more researches have been carried out in the vicinity of Hanoi and along the banks of the Red River.

In a more recent study, Winkel et al. (2011) did a research on a large scale in the Red River Delta. The results showed that $27 \%$ of the studied wells exceeded the WHO guideline value, which means about three million people used groundwater contaminated with arsenic concentration $>10 \mu \mathrm{g} / \mathrm{L}$ and one million people used groundwater with the arsenic concentrations $>50 \mu \mathrm{g} / \mathrm{L}$. It is quite a concern because the Red River Delta is one of the most densely populated regions in the world, with a population density of about 1000 people $/ \mathrm{km}^{2}$ covering an area of $21,000 \mathrm{~km}^{2}$ (General Statics Office of Vietnam, 2015).

However, there still is an unanswered question about arsenic distribution that is how two wells only $50 \mathrm{~m}$ away from each other can have a different arsenic concentration. Study of Eiche et al. (2008) in Van Phuc village (about $10 \mathrm{~km}$ Southeast of Hanoi), where groundwater is exploited as the main source of drinking water, showed the same phenomena: very different arsenic concentrations were obtained at two sites $700 \mathrm{~m}$ apart (one had the concentration $<10 \mu \mathrm{g} / \mathrm{L}$ and one ranged from $170-600 \mu \mathrm{g} / \mathrm{L}$ ). In their study in 2013, van Geen et al. found out that due to the groundwater pumping, arsenic can move from the Holocene aquifer into a previously uncontaminated Pleistocene aquifer. This might be the explanation for the difference in arsenic distribution in groundwater; however, this can only be applied to a specific area.

In this study, groundwater from a transect in the Northeast-Southwest direction in the Northwestern Hanoi was examined. Different from Van Phuc village in the aforementioned studies of Eiche and Van Geen, this is a less dense area where groundwater chemical composition is less affected by human activities. Therefore, this is an appropriate area to study the natural occurrence and distribution of arsenic in groundwater. The objectives of this study are (i) to investigate the spatial variations of arsenic concentration in groundwater of the area in the Northwestern Hanoi to see whether or not the groundwater here contains arsenic; (ii) to investigate the relationship between arsenic and some chemical compounds and (iii) to partially predict the tendency of arsenic concentration in groundwater.

\section{Methodology}

\subsection{Research area}

The research area is located in the North West of Hanoi and about $30 \mathrm{~km}$ away from the city center. This location of this area is between Ba Vi Mountain and the Red River, including a part of the Day River. This is the area with lower population density, where there is neither groundwater exploit for irrigation nor any water supply plants using groundwater. Therefore, the impact of human activities 
Vietnam Journal of Earth Sciences, 40(1), 70-77

on the chemical composition and distribution in groundwater is limited.

For this study, observation wells were constructed alongside the transect: Cam Yen Phuc Hoa - Xuan Phu - Van Phuc (B-B' transect) (Figure 1).

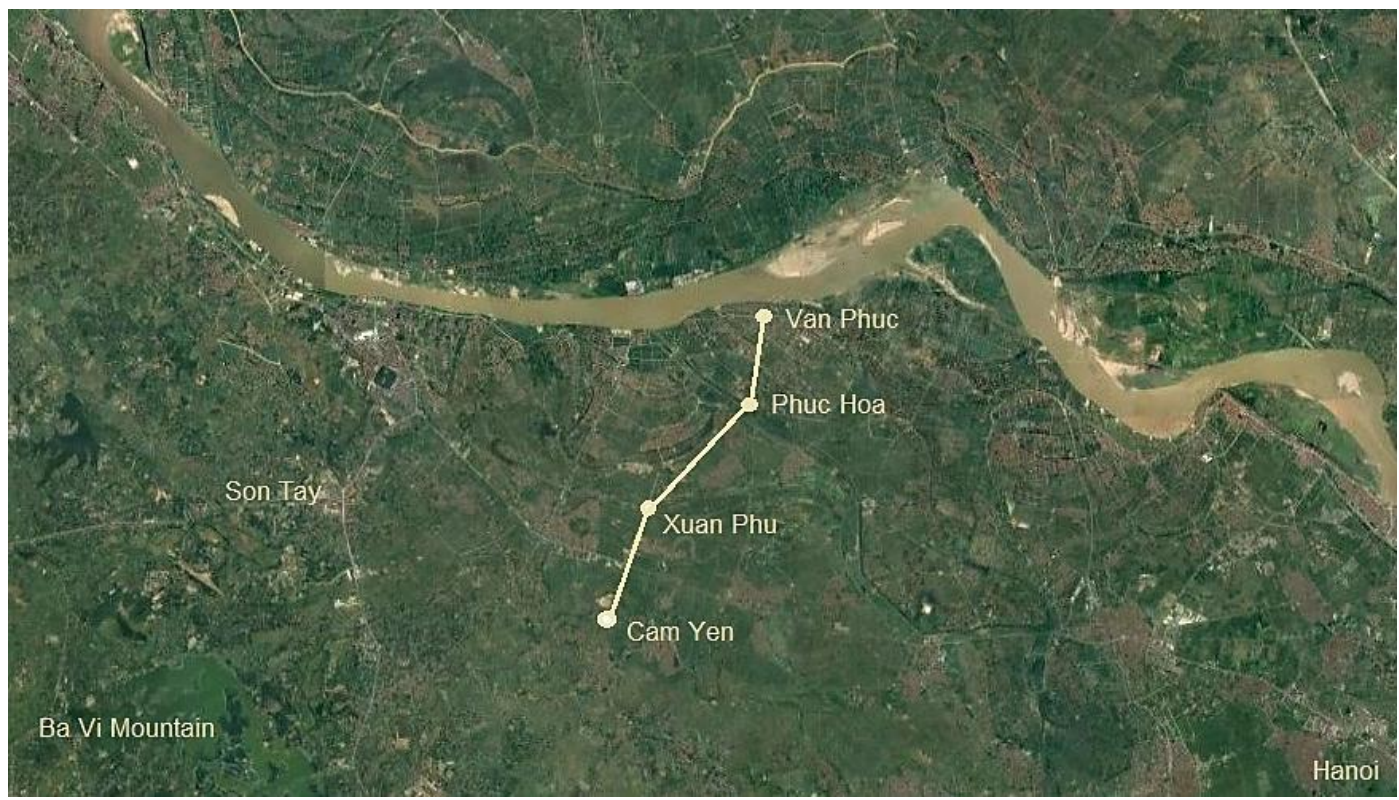

Figure 1. Research transect

Among the four points of the transect, Cam Yen is the closest to the Ba Vi Mountain (approximately $16 \mathrm{~km}$ ) and Van Phuc is the closest to the Red River (approximately $1 \mathrm{~km}$ ).

The cross-section of the research transect is shown in Figure 2. The uppermost layer of this area is clay layer. Beneath that are the silty sand and sandy layer. And at the bottom is the gravel layer. The depth of the constructed wells depends on the depth of the sand level in the aquifer. From Figure 2, one can see that the depth of the wells at Xuan Phuc varies in the smallest range, while the wells at Phuc Hoa have the widest variation in depth.

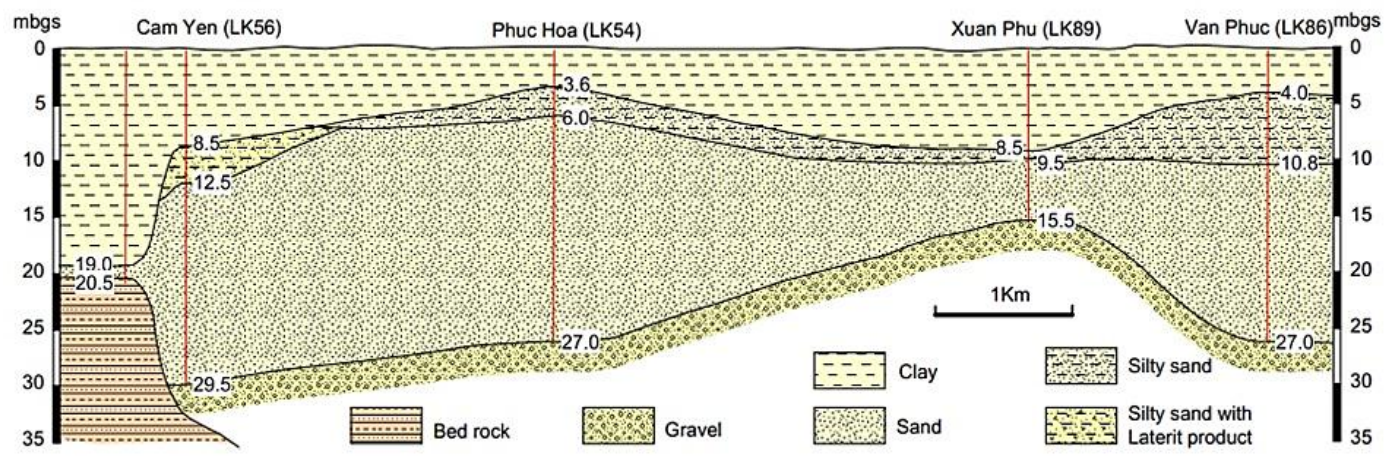

Figure 2. Cross-section of the research transect

To be more precise, the depth of the observation wells which are constructed for this study at Cam Yen are 13.27-28.79 m (16 wells), at Phuc Hoa are 6.5-26.7 m (18 wells), 
at Xuan Phu are 10.02-15.47 $\mathrm{m}$ (7 wells) and at Van Phuc are 11.78-26.88 $\mathrm{m}$ (16 wells). The total number of groundwater samples is 57 .

\subsection{Sampling of groundwater}

After the wells were constructed, they were rested for approximately 3 months before sampling to stabilize the geological conditions and chemical composition of water. Groundwater water was sampled from the borehole using a down hole pump. Before taking the water samples from the wells, 3 to 5 borehole volumes of the well were flushed. During flushing, a flow cell equipped with $\mathrm{pH}, \mathrm{EC}$ and $\mathrm{DO}$ electrodes was mounted directly on the sampling tube. The water samples will be taken only until the values of $\mathrm{pH}$, EC and DO were stable.

$\mathrm{CH}_{4}$ samples were injected directly from the sampling tube into a preweighed evacuated glass vial, leaving a headspace of one-half to two-thirds of the total volume. After sampling, the samples were frozen immediately in an upside down position to avoid sample leakage. Samples for other parameters were collected in the syringes and filtered through $0.45 \mu \mathrm{m}$ cellulose acetate filters. As (V) and As (III) were separated using an anion exchange cartridge, contained $0.8 \mathrm{~g}$ aluminosilicate adsorbent to adsorb As (V).

Cation determination samples were kept in $50 \mathrm{~mL} \mathrm{PE}$ bottles, using $\mathrm{HNO}_{3}$ 1:1 to preserve. DOC determination samples were kept in $24 \mathrm{~mL}$ baked glass vials and preserved by $\mathrm{HCl} 1: 1$.

\subsection{Laboratory analysis}

Cations were determined using Shimadzu atomic absorption spectrophotometer instrument (AA 6800). Arsenic was measured using the same instrument with an HVG hydride generator. Anions were determined by ion chromatography using a Shimadzu LC20AD/HIC-20ASuper. $\mathrm{CH}_{4}$ head space concentrations were determined by gas chromatography using a Shimadzu GC-14A. $\mathrm{NH}_{4}$ concentrations were determined by Shimadzu spectrophotometer UV-Vis 1800 . DOC concentrations were determined by Shimadzu TOC V-CSH. \%RSD of all analysis was under $2 \%$ with the recovery from $95-105 \%$.

\section{Results and Discussions}

The total arsenic concentrations from groundwater of the B-B' transect ranged from $<5$ to $115 \mu \mathrm{g} / \mathrm{L}$. Among them, only 5 wells at Van Phuc and 1 well at Xuan Phu contained more than $50 \mu \mathrm{g} / \mathrm{L}$ of arsenic $(10.5 \%$ of the observation wells). The average concentration at Cam Yen was the lowest $(<5 \mu \mathrm{g} / \mathrm{L})$, whereas the average concentration at Van Phuc was the highest $(50 \mu \mathrm{g} / \mathrm{L})$ (Figure 3). However, if compared with the WHO guidelines for arsenic concentrations for drinking water, only the wells at Cam Yen, 1 well at Phuc Hoa and 1 well at Xuan Phu met the limitation value (28.8\% of the well). Therefore, most of these wells water cannot be used for drinking.

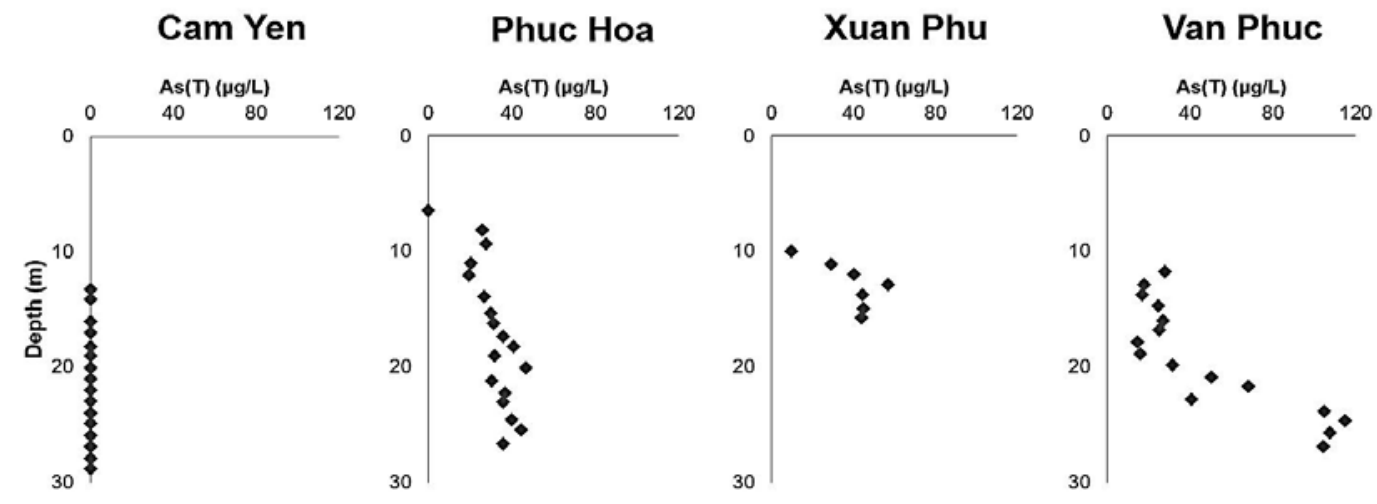

Figure 3. Total Arsenic concentrations in groundwater from the B-B' transect 
Vietnam Journal of Earth Sciences, 40(1), 70-77

It can be seen also that the As concentrations increased from Cam Yen to Van Phuc. As mentioned before, Van Phuc is the closest to the Red River, which carries heavy sediment loads, together with organic and inorganic matters. When this sediment deposits, these organic compounds stay in the soil. With that being said, the sediment at Van Phuc is expected to be the richest in organic compounds among the four points. This also means that the intensity of reduction activities in Van Phuc will be higher than other location, thus intensify the dissolution process of iron oxides minerals, which controls the release of As.

On the other hand, the sediment at Cam Yen is the farthest from the Red River, which suggests that there are not many organic compounds in the sediment here. This will lead to the less of reduction activities, and as a result, less in Arsenic concentrations.

Another indication of organic compounds contents in sediment is the Ec value. The high concentrations of organic compounds will lead to the degradation process of organic matters and release $\mathrm{CO}_{2}$ into groundwater. This $\mathrm{CO}_{2}$ will take part in the dissolution process of minerals and thus, increases the Ec value (Appelo \& Postma, 2004). Figure 4 shows the EC results of the transect. The Ec values at Van Phuc were approximately $1100 \mu \mathrm{S} / \mathrm{cm}$. This is much higher than the Ec found in the Red River, which is $290 \mu \mathrm{S} / \mathrm{cm}$ (Postma et al., 2007). Whilst, the Ec values at Cam Yen were around $200 \mu \mathrm{S} / \mathrm{cm}$.

This is corresponding with Postma's results in his study in 2012. In this study, he found that the highest As concentrations were detected at the H-transect, which is closest to the Red River. While the lowest ones were found at Phung Thuong, which is farther from the River. He also concluded that the As concentrations in groundwater were proved to be in correlation with sediment burial age. The younger the sediment is, the higher arsenic was found in groundwater. Therefore, the sediment in Cam Yen is predicted to be the oldest among the four points. The sediment then is younger at Phuc Hoa, Xuan Phu and Van
Phuc are believed to be the youngest because it is the closest to the Red River.

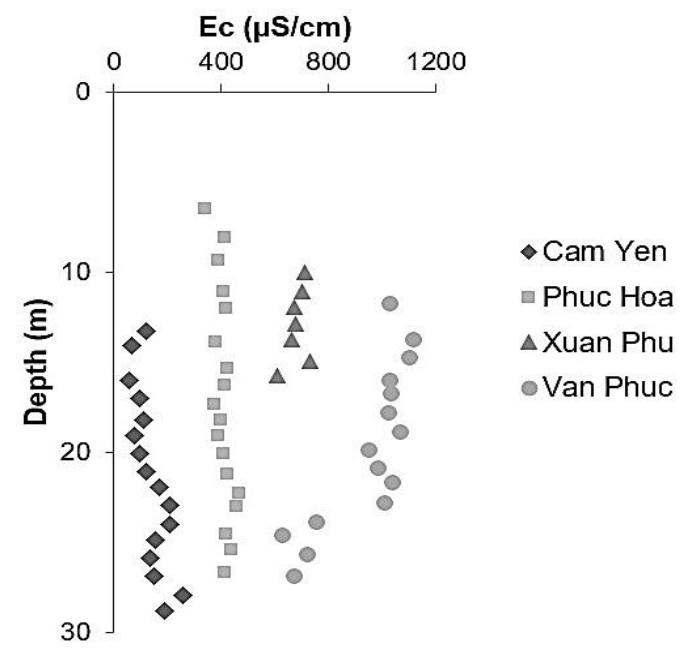

Figure 4. Ec values of the four sites from the B-B' transect

Not only varied from point to point, the As concentrations also varied with depth. At Cam Yen, the As concentrations were practically similar for all the depths. But at Phuc Hoa, Xuan Phu and Van Phuc, the As concentrations generally increased with depth. The As concentrations at Van Phuc varied the most with depth, with the lowest concentration (15 $\mu \mathrm{g} / \mathrm{L})$ was found at the depth $17.8 \mathrm{~m}$, while the highest one $(115 \mu \mathrm{g} / \mathrm{L})$ was found at the depth $24.6 \mathrm{~m}$. It was the same for Xuan Phu. The variation range of As concentrations at Phuc Hoa was less wildly.

The variations of DOC and $\mathrm{NH}_{4}$ concentrations in groundwater of this transect were quite similar. At Cam Yen, Phuc Hoa and Van Phuc, the maximum values of DOC and NH4 were found at the depth of $20-25 \mathrm{~m}$, and at the depth of $15 \mathrm{~m}$, the DOC and $\mathrm{NH}_{4}$ concentrations at Xuan Phu reached the highest values. As for $\mathrm{CH}_{4}$, the concentrations at Xuan Phuc and Van Phuc had the same trends with DOC and $\mathrm{NH}_{4}$, while in Cam Yen and Phuc Hoa, the $\mathrm{CH}_{4}$ concentrations did not show huge differences between different depths.

According to Smedley \& Kinniburgh (2002) and Fendorf et al. (2010), one of the principal causes of high As concentrations in water is the reductive dissolution of hydrous $\mathrm{Fe}$ 
oxides. As Fe oxides dissolve under strongly reducing conditions, one can predict that the stronger the reducing conditions are, the higher As concentrations occur in groundwater. This tendency was indeed found in the groundwater of the B-B' transect. Figure $5 \mathrm{a}$ and $5 \mathrm{~b}$ showed the occurrence between As concentrations and DOC, $\mathrm{CH}_{4}$ and $\mathrm{NH}_{4}$ concentrations, which are the chemical compounds representing the re- ducing environment. The concentrations of these compounds increased in the deeper wells indicated that the reduction conditions got stronger when it goes deeper. It is the favorable condition for the dissolution of Fe oxides, and therefore favorable for As releasing. This is one of the explanations for the variation of As concentrations with depth at Phuc Hoa, Xuan Phu, Van Phuc.

\section{Cam Yen}
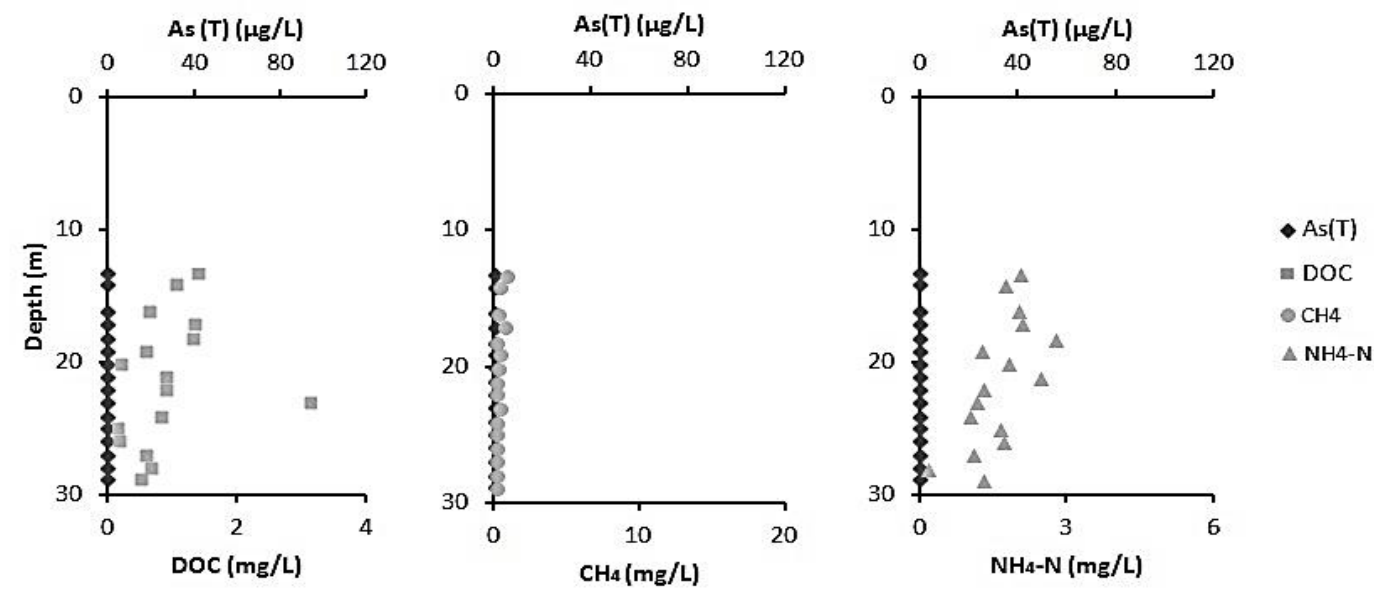

Phuc Hoa
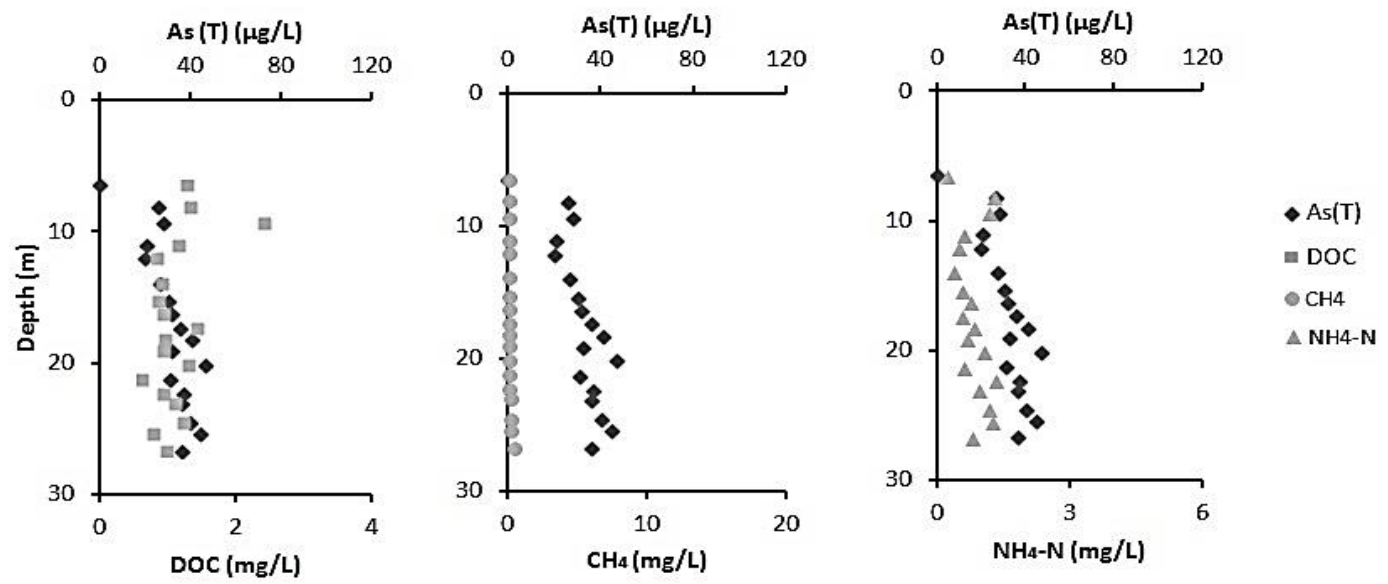

Figure 5a. Occurrence of arsenic and other reducing condition instruction compounds in groundwater at Cam Yen - Phuc Hoa

As founded in the study on Bangladesh groundwater of MacArthur et al. (2001), ar- senic will not be released from the iron minerals without the presence of organic matter 
Vietnam Journal of Earth Sciences, 40(1), 70-77

to drive microbial reduction. This is also the case for the B-B' transect. From the concentrations of DOC and $\mathrm{CH}_{4}$ in Figure $5 \mathrm{a}$ and $5 \mathrm{~b}$, which are indicators for the contents of organic matters, one can also see that the or- ganic matters at Xuan Phu and Van Phuc were higher than at Cam Yen and Phuc Hoa. And the higher concentrations of DOC and $\mathrm{CH}_{4}$ corresponded with higher arsenic concentrations.

\section{Xuan Phu}
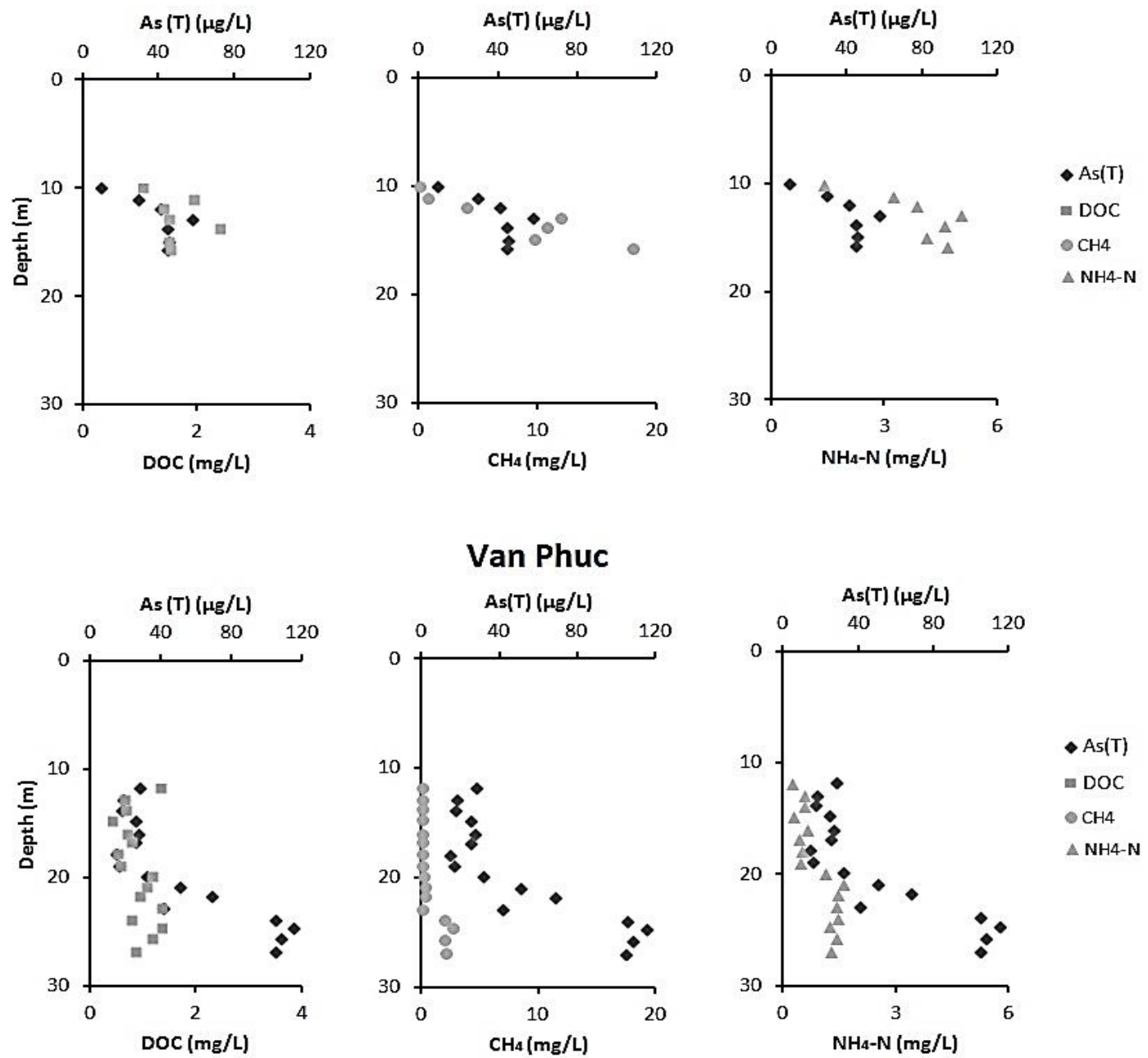

Figure 5b. Occurrence of arsenic and other reducing condition instruction compounds in groundwater at Xuan Phu - Van Phuc

\section{Conclusions}

The arsenic concentrations of the B-B' transect vary in a wide range: from $<5$ to 115 $\mu \mathrm{g} / \mathrm{L}$, with the lowest average concentration at Cam Yen and the highest one at Van Phuc. The As release process depends on many fac- tors such as the extent of the reducing conditions, the sediment age, bacteria activities, etc.

From the results, one can predict the tendency of As that the As concentration will increase while the distance to river decrease. The place closer to the mountain part will 
Dao Viet Nga, et al./Vietnam Journal of Earth Sciences 40 (2018)

have lower concentration, whereas the high concentration will be found at the place closer to the river. The As concentration is also proportional to the depth. The deeper the well is, the higher As concentration it has.

\section{Acknowledgements}

This study was done at the VSL Laboratory (VNU-Shimadzu join laboratory for analytical sciences) at the Research center for Environmental Technology and Sustainable Development (CETASD), as part of the research project "Predicting the arsenic content in groundwater of the floodplains in Southeast Asia", co-operated between VNU University of Science, Hanoi University of Mining and Geology (HUMG) and Geological Survey of Denmark and Greenland (GEUS). The authors would like to thank also the European Union (EU) for their financial support.

\section{References}

Anawar H.M., Akai J., Sakugawa H., Sakugawa H., 2004. Mobilization of arsenic from subsurface sediments by effect of bicarbonate ions in groundwater. Chemosphere, 54, 753-762.

Appelo C.A.J., Postma D., 2004. Geochemistry, Groundwater and Pollution, second edition.

Berg M., Tran H.C., Nguyen T.C., Pham H.V., Schertenleib R., Giger W., 2001. Arsenic contamination of groundwater and drinking water in Vietnam: A human health threat. Environmental Science \& Technology, 35(13), 2621-2626.

Berg M., Stengel C., Pham T.K.T., Pham H.V., Sampson M.L., Leng M., Samreth S., Fredericks D., 2007. Magnitude of arsenic pollution in the Mekong and Red River Delta - Cambodia and Vietnam. Science of the Total Environment, 372, 413-425.

Chowdhury U.K., Biswas B.K., Chowdhury T.R., Samanta G., Mandal B.K., Basu G.C., Chanda C.R., Lodh D., Saha K.C., Mukherjee S.K., Roy S., Kabir S., Quamruzzaman Q., Chakraborti D., 2000. Groundwater Arsenic Contamination in Bangladesh and West Bengal, India. Environmental Health Perpectives, 108(5), 393-397.

Eiche E., Neumann T., Berg M., Weinman B., Van Geen A., Norra S., Berner Z., Pham T.K.T., Pham H.V., Stuben D., 2008. Geochemical processes underlying a sharp contrast in groundwater arsenic concentrations in a village on the Red River delta, Vietnam. Applied Geochemistry, 23, 3143-3154.

Fendorf S., Michael H.A., Van Geen A., 2010. Spatial and temporal variations of groundwater arsenic in South and Southeast Asia. Science, 328, 1123. Doi: $10.1126 /$ Science. 1172974.

General Statics Office of Vietnam, 2015. Regional statistics of Area, Population and Population density.

McArthur J.M., Ravenscroft P., Safuilla S., Thirlwall M.F., 2001. Arsenic in groundwater: Testing pollution mechanisms for sedimentary aquifers in Bangladesh. Water Resources Research, 31(1), 109-117.

Postma D., Larsen F., Nguyen T.M.H., Mai T.D., Pham H.V., Pham Q.N., Jessen S., 2007. Arsenic in groundwater of the Red River floodplain, Vietnam: Controlling geochemical processes and reactive transport modeling. Geochimica et Cosmochimica Acta, 71, 5054-5071.

Postma D., Larsen F., Nguyen T.T., Pham T.K.T., Jakobsen R., Pham Q.N., Tran V.L., Pham H.V., Murray A.S., 2012. Groundwater arsenic concentrations in Vietnam controlled by sediment age. Nature GeoScience. Doi: 10.1038/NGEO1540.

Smedley P.L., Kinniburgh D.G., 2002. A review of the source, behavior and distribution of arsenic in natural waters. Applied Geochemistry, 17, 517-568.

Smedley P.L., 2006. Sources and distribution of arsenic in groundwater and aquifers. In T. Appelo (Ed.), Arsenic in Groundwater - A World Problem, 4-33.

Van Geen A., Bostick B.C., Pham T.K.T., Vi M.L., Nguyen N.M., Dao M.P., Pham H.V., Radloff K., Aziz A., Mey J.L., Stahl M.O., Harvey C.H., Oates P., Weinman B., Stengel C., Frei F., Kipfer R., Berg M., 2013. Retardation of arsenic transport through a Pleistocene aquifer. Nature, 501, 204-208.

Van Geen A., Zheng Y., Versteeg R., Stute M., Horneman A., Dhar R., Steckler M., Gelman A., Small C., Ahsan H., Graziano J.H., Hussain I., Ahmed K.M., 2003. Spatial variability of arsenic in 6000 tube wells in a $25 \mathrm{~km}^{2}$ area of Bangladesh. Water Resources Research, 39(5), 1140. Doi:10.1029/2002WR001617.

World Health Organization, 2011. Guidelines for drinking-water quality, fourth edition.

Winkel L.H.E., Pham T.K.T., Vi M.L., Stengel C., Amini M., Nguyen T.H., Pham H.V., Berg M., 2011. Arsenic pollution of groundwater in Vietnam exacerbated by deep aquifer exploitation for more than a century. PNAS, 108(4), 1246-1251. 